\title{
PROCESSES OF NUTRITION, METABOLISM, BIOSYNTHESIS OF MILK COMPONENTS AND VITALITY OF COWS WITH HIGH AND LOW-FAT MILK
}

\section{Evgeniy Kharitonov}

All-Russia Research Institute of Animal Physiology, Biochemistry, and Nutrition, Branch of Ernst Russian Institute of Animal Breeding Federal Science Center for Animal Husbandry

Borovsk, Russia

e-mail : evgenijkharito@yandex.ru

\section{Simple Summary}

On highly productive cows of various fat content at the end of the first phase of lactation, the features of scar fermentation, the formation of substrates and their use in energy metabolism and biosynthesis of milk components were studied. It was found that low milk fat is not associated with a lack of acetate formation in the rumen and a change in the hormonal profile, but depends on a decrease in the synthesis of de novo fatty acids, the regulation of which is carried out by conjugated higher fatty acids. The result is a reduction in the need of cows for metabolic energy, the likelihood of ketosis and the extension of their productive use.

\section{Abstract}

The trials were performed on 20 multiparous cows of Holstein breed $(39.7 \pm 0.75 \mathrm{~kg}$ of milk) at the end of the first phase of lactation this different milk fat (4.1-2.8\%). The aim of the research was to study the characteristics of nutrition, metabolism and biosynthesis of milk components in highly productive dairy cows with normal and low milk fat levels and the timing of their productive use. Study the characteristics of fermentation of scar formation substrates and their use in energy metabolism and biosynthesis of the milk components. Found that low fat milk is not associated with a lack of formation of acetate in the rumen $(6.1 \mathrm{vs} .6 .6 \mathrm{mmol} / \mathrm{dl}$ in the contents of the rumen, $\mathrm{p}>0.05)$ and the non change in the hormonal profile, but depends on the reduction of fatty acids synthesis de novo in mammary gland, regulated by conjugated higher fatty acids. The result is a reduction in the need of cows in the exchange energy (reduction of heat transfer by $6.2 \mathrm{MJ}$ ), a shorter service period (109.5 vs.139 days) and the prolongation of their productive use (the number of lactations correlated back with the level of fat in milk $(r=-0.68, \mathrm{p}<0.05, \mathrm{n}=1300)$.

Keywords: cows; milk fat; ruminal fluid; milk fatty acids, energy balance

\section{Introduction}

Intensification of dairy farming, further increase in the productivity of cows requires maintaining the normal physiological state of animals, which is the key to their long-term productive use and a guarantee of obtaining high quality milk. Only a healthy cow is able to provide high productivity. Therefore, the health of the cow and her productivity are inextricably linked. In recent years, the number of diseases of alimentary etiology has increased significantly. The main breakdown 
occurs in the first months of lactation, when the feed consumption potential lags behind the growth rate of milk production.

Ensuring high milk productivity while maintaining the timing of economic use and reproductive function in cows is one of the most urgent tasks of modern dairy farming. One of the main reasons for this phenomenon is considered to be chronic ketosis of highly productive cows due to poor feed quality and insufficient diet balancing. The disease is diagnosed in countries with highly developed dairy cattle breeding, in particular in the USA, Canada, Germany, Holland, Denmark. In the United States, about 1 million ketosis diseases are reported annually (4\% of the population). This pathology causes significant economic damage to livestock farms, which is characterized by a reduction in the term of use of the most valuable highly productive animals to 3-4 years, a decrease in productivity to $30-50 \%$, loss of live weight, forced culling of animals, as well as a significant number of barren cows after getting sick and negative influence on the of spring. The root cause of metabolic ketosis is a significant lack of energy in the diet. It is possible to reduce it by correct rationing using the main high-quality feeds, increasing the concentration of energy in the diet due to concentrates (in controlling the occurrence of acidosis) or "protected" fats. If the energy deficit in the diet cannot be overcome at present, then it is required to help the cow cope with the emerging metabolic situation leading to ketosis.

High-producing dairy cows in early lactation often have a negative balance of energy, which leads to increased mobilization of fat stores and contributes to the development of various diseases. As the results of the monitoring study conducted in a number of regions of the country showed, this problem is still relevant [1]. As part of the implementation of the program to improve the feeding system of dairy cattle, methods for regulating the intensity of biosynthesis of individual milk components are being developed, ensuring the preservation of the health of highly productive dairy cows and obtaining products of the required quality. One approach to preventing energy deficiencies in cows at the beginning of lactation is the use of drugs that contribute to reducing energy deficiencies by reducing the biosynthesis of milk fat $[2,3]$. In the search for such a regulator in recent years, the biological effect of the addition of a mixture of positional and geometric isomers of octadecadienoic acid with conjugated bonds (conjugate linoleic acid, CLA) has been studied [4, 5]. There was a whole trend - the use of the CLA supplement as a fat-depleting dietary component [6, 7]. Infusion into the abomasum of an additive containing $60 \%$ CLA caused more than $50 \%$ reduction in the fat content of milk at all tested doses of administration; while virtually no change in milk yield and other indicators of dairy products [8]. In another experiment, it was found that intramuscular administration of CLA at a dose of 20, 40 and 80 g caused a decrease in milk fat by 36, 43 and 62\%, respectively [9]. Later it was found that the decrease in milk fat, observed with additives in the diet of CLA, is due mainly to the action of the trans-10 isomer, cis-12 C18: 2 . Usually when performing experiments on dairy cows to exclude fermentation in the rumen, CLA is infused into abomasum [10], but there are CLA protection technologies against rumen bacteria.

The biochemical mechanisms of inhibiting the synthesis of milk fat under the influence of CLA are not fully understood. It is believed that the decrease in the fat content caused by trans-10, cis-12 isomer of linoleic acid, can be due to inhibition of lipogenesis and tissue $\Delta 9$-desaturase activity $[11,12,13]$. Since only short- and medium-chain fatty acids are synthesized in the mammary gland, the fatty acid composition of milk lipids must change during inhibition of their synthesis, but this effect is not revealed in the application of CLA. Therefore, the mechanisms by which CLA reduce the synthesis of milk fat, can be multifaceted and include shifts in other systems, including endocrine.

It is known that the endocrine system plays a leading role in preparing cows for calving and forming a lactational dominant, which is accompanied by a change in the ratio of blood concentrations of a number of hormones; first of all, the secretion of insulin decreases and the level of somatotropin in the blood increases [14]. This changes the intensity of the main processes of protein, carbohydrate and lipid metabolism; the intake from muscle and adipose tissue into the secretory cells of the breast of the metabolites necessary for the biosynthesis of milk components (amino acids, fatty acids, glucose, etc.) increases. The mechanisms and factors that regulate these processes in cows at different periods of the reproductive cycle have not been adequately studied. Therefore, the study of biological 
factors and mechanisms of regulation of the functional activity of the endocrine glands is an actual scientific problem.

The aim of the research was to study the characteristics of nutrition, metabolism and biosynthesis of milk components in high-productivity cows with high and low levels of milk fat in order to clarify the mechanism of depression of milk fat formation in the algorithm and preserve the health of animals.

\section{Materials and methods}

Fulfilled work was made in accordance with ethical principles established by the European convention on vertebrates' protection which are used for experimental and other scientific purposes (adopted in Strasbourg 18.03.1986 and ratified in Strasbourg 15.06.2006). The work was approved by ethic Committee of the all-Russian scientific research Institute of physiology, biochemistry and nutrition, Borovsk (Kaluga region, Russia) (Protocol №8 from 12.05.2019).

\subsection{Experiment Design and Animal Management}

The studies were carried out on cows of the Holstein breed of 2nd lactation at the end of the first phase (80 day) with milk for the previous lactation of 8-9 thousand $\mathrm{kg}$ of milk. Based on the data of the control milking, milk composition, lactation day, fatness, lactation number, two groups of cows (10 heads each) were found in the same feeding group (a group of highly productive cows), but with different fat content of milk according to the results of the last control milking (Table1). At the same time, by origin (assigned bull-producer), the cows in the groups did not differ.

Table 1 Characteristics of cows in the experiment $(M \pm S E ; n=10)$

\begin{tabular}{|l|c|c|c|c|c|c|}
\hline $\begin{array}{l}\text { Groups of } \\
\text { cows }\end{array}$ & $\begin{array}{l}\text { live } \\
\text { weight, kg }\end{array}$ & $\begin{array}{l}\text { number of } \\
\text { lactation }\end{array}$ & $\begin{array}{l}\text { stage of } \\
\text { lactation } \\
\text { (days) }\end{array}$ & $\begin{array}{l}\text { Milk yield, } \\
\mathrm{kg} / \mathrm{d}^{-}\end{array}$ & Milk fat, \% & $\begin{array}{l}\text { Milk } \\
\text { protein, } \%\end{array}$ \\
\hline $\begin{array}{c}\text { cows with } \\
\text { normal milk } \\
\text { fat (Group 1) }\end{array}$ & $625 \pm 23,7$ & $1,5 \pm 0,2$ & $57,0 \pm 6,53$ & $41,2 \pm 1,79$ & $3,94 \pm 0,12$ & $3,18 \pm 0,08$ \\
\hline $\begin{array}{c}\text { cows with } \\
\text { low milk fat } \\
\text { (Group 2) }\end{array}$ & $629 \pm 30,9$ & $1,6 \pm 0,31$ & $58,0 \pm 12,2$ & $39,5 \pm 1,55$ & $2,95 \pm 0,14$ & $3,12 \pm 0,07$ \\
\hline $\begin{array}{c}\text { Contrast (P- } \\
\text { value) }\end{array}$ & 0,54 & 0,48 & 0,46 & 0,21 & 0,0005 & 0,5 \\
\hline
\end{tabular}

In all periods of experiment of a cow obtained a ration from keeping 50- $60 \%$ of concentrated foods on nutritiousness. A feeding of cows - double at 8.00 and 18.00. The ration has been designed for reception 40кг milk (Table 2) and was set in the form of a feed mixture. The feeding ration for all groups of cows was the same, consistent with the level of milk production, live weight and day of lactation and was within the limits of the allowed content of individual nutrients. The cows' diet was represented by silage corn $(20 \mathrm{~kg})$, haylage of perennial grasses $(8 \mathrm{~kg})$, hay grass $(0.5 \mathrm{~kg})$, mixed fodder $(16 \mathrm{~kg})$, soybean meal $(1 \mathrm{~kg})$, fresh beer pellet $(6 \mathrm{~kg})$, molasses $(1 \mathrm{~kg})$.

Table 2 Composition of total mixed diet fed to cows 


\begin{tabular}{|c|c|}
\hline Composition & $\%$ of $\mathrm{DM}$ \\
\hline copped grass hay & 1,6 \\
\hline haylage of perennial grasses & 8,0 \\
\hline corn silage & 23,9 \\
\hline compound feed & 52,1 \\
\hline beer shot & 7,8 \\
\hline soybean meal & 3,3 \\
\hline molasses & 2,9 \\
\hline sodium bicarbonate & 0,1 \\
\hline tricalcium phosphate & 0,15 \\
\hline Salt plus trace mineralized salt and vitamins & 1.9 \\
\hline Chemical composition & $(\%$ of $\mathrm{DM})$ \\
\hline $\mathrm{OM}$ & 93.4 \\
\hline $\mathrm{CP}$ & 16.5 \\
\hline NDF & 33.1 \\
\hline Forage NDF & 19.7 \\
\hline $\mathrm{ADF}$ & 17.5 \\
\hline Total FA & 3.86 \\
\hline Starch & 23.4 \\
\hline $\mathrm{OE}(\mathrm{MDJ} / \mathrm{kg})$ & 9.91 \\
\hline
\end{tabular}

DM: dry matter, OM: organic matter CP: crude protein, NDF: neutral detergent fiber, ADF: acid detergent fiber, FA = fatty acids OE: metabolizable energy

Compound feed consisted of: wheat $20 \%$, barley $33 \%$, oats $5 \%$, maize $13 \%$, sunflower meal $25 \%$, salt $1 \%$, minoadditives $1 \%$, premix $1 \%$.

Salt plus trace mineralized salt and vitamins contained $38.5 \% \mathrm{NaCl}$ and $61.5 \%$ of a trace mineral and vitamin mix. Trace mineral and vitamin mix contained $0.11 \% \mathrm{Mn}, 0.14 \% \mathrm{Zn}, 0.05 \% \mathrm{Fe}$, $0.025 \% \mathrm{Cu}, 0.0027 \% \mathrm{I}, 0.0024 \% \mathrm{Co}$, and $0.0007 \% \mathrm{Se}$. It also contained 750,000 IU of vitamin A, $280,000 \mathrm{IU}$ of vitamin D3, and $2560 \mathrm{IU}$ of vitamin E per $\mathrm{kg}$ of mix.

\subsection{Sample Collection and Measurement}




\subsubsection{Rumen Fluid Collection and Measurement}

Samples of a rumen liquid obtained after 3 hours after morning feeding with the help oral gastric tube. The initial $100 \mathrm{~mL}$ of rumen fluid was discarded to avoid saliva contamination, and finally, $100 \mathrm{~mL}$ of rumen fluid was filtered by four layers of cheesecloth and then collected. The rumen fluid $\mathrm{pH}$ was immediately measured using a $\mathrm{pH}$ electrode (OHAUS Starter ST2100-B) after collection. Immediately after rumen fluid collection, a $10 \mathrm{~mL}$ aliquot of ruminal fluid supernatant was preserved by adding $1 \mathrm{~mL}$ of $25 \%$ metaphosphoric acid for volatile fatty acid (VFA) determination, and another $50 \mathrm{~mL}$ aliquot of untreated ruminal fluid was kept for others analysis.

The $\mathrm{NH}_{3}-\mathrm{N}$ concentration was measured using microdiffusion method in Conway dishes, total VFA in the Martgama apparatus, the number of bacteria and protozoa microscopically, the amylolytic and fibrolytic activity incubation method (Cotton thread № 10 and $20 \%$ potato starch solution were taken as the sources of nutrients) described by Kurilov [15].

Samples of ruminal fluid were analyzed for VFA using a gas chromatograph (Colour -800 , Rus) equipped with a Hromaton N-AWDMCS (Chech) fused-silica capillary column $(1,5 \mathrm{~m} \times 3 \mathrm{~mm}$ i.d., with $0.2-\mu \mathrm{m}$ film thickness). A flame ionization detector was used with an oven initial temperature of $120^{\circ} \mathrm{C}$ and maximum temperature of $250{ }^{\circ} \mathrm{C}$ and an equilibrium time of $0.50 \mathrm{~min}$. The detector temperature was $120{ }^{\circ} \mathrm{C}$, hydrogen carrier gas flow to the detector was $40.0 \mathrm{~mL} / \mathrm{min}$, airflow was $450 \mathrm{~mL} / \mathrm{min}$ and the flow of nitrogen makeup gas was $45.0 \mathrm{~mL} / \mathrm{min}$. A volatile free acid mixture standard (MTY-1075 Matreya LLG, USA) was used for VFA determination.

\subsubsection{Indicators of energy metabolism in cows}

The heat production was measured by the method of indirect calorimetry in respiratory trials using face masks [16]. Immediately after exhaled gases collection analysis $0_{2}$ and $\mathrm{C}_{2}$ of was curried out on a gas analyzer-chromatograph (AHT-TI, Rus). The gross energy of the diets and milk samples was determined using an adiabatic bomb calorimeter (ABK-1, Rus).

\subsubsection{Plasma Samples}

Blood samples were obtained by puncture of the caudal artery and dairy vein were transferred into non-heparinized vacutainers (BD Vacutainer, Plymouth, UK). Serum samples were obtained from blood after centrifugation at $2000 \times \mathrm{g}$ for $15 \mathrm{~min}$ at $4{ }^{\circ} \mathrm{C}$. Serum was preserved at $-20^{\circ} \mathrm{C}$ until analysis. In the blood serum, the glucose (GLU) content was determined with the help of a of enzymatic colorimetric method (the panel of reagents of firm «Soared Diagnostic, SPb RUS»), the concentration of non-esterified fatty acid (NEFA) was determined by means of enzymatic colorimetric method (kit «Rendox» UK), $\beta$-hydroxybutyrate (a set of reagents from Rendox), volatile fatty acids (VFA) (on a gas chromatograph Colour - 800), urea (a set of reagents" Urea 450 "from the firm" Lahema "), $\alpha$-amine nitrogen [17], triacylglycerols of enzymatic colorimetric method ((the panel of reagents of firm «Soared Diagnostic, SPb RUS ). In blood plasma samples, the concentration of insulin, thyroxine, triiodothyronine, cortizol were determined by an enzyme immunoassay using commercial kits (DRG, Germany).

In blood plasma, the activity of pyruvate carboxylase was determined by the method [18] and lactate dehyrogenase LDH - using a set of Lahem's company, when NAD was introduced into the reaction medium to determine the rate of conversion of lactate to pyruvate, The amount of acetoaldehyde was determined at $340 \mathrm{~nm}$ on a Specol-11 spectral colorimeter (Carl Zeiss, Germany) after preliminary preparation. Definition $\alpha$-tocopherol, retinol, thiamine using a chromatograph (Millichrom, RUS).

The arterio -venous difference (caudal artery -dairy vein) of the concentration of key metabolites in the mammary gland and the efficiency of their absorption were determined. 


\subsubsection{Milk Composition Analysis}

Samples of milk from three consecutive days were combined according to yield for each day and for each cow. The milk was sampled in a $50 \mathrm{~mL}$ tube and analyzed immediately. The samples were analyzed using a milk analyzer («Lactostar, $\mathrm{GmbH»)}$ for protein, fat, lactose, urea nitrogen.

\subsubsection{Fatty Acid Analysis}

Lipids from milk were extracted according to Folch [19] by using methanol: chloroform: (2:1); then transmethylated. For analysis of FA, using a gas chromatograph (Colour -800 , Rus) equipped with a Hromaton AWYMDS fused-silica capillary column $)(1.5 \mathrm{~m} \times 3 \mathrm{~mm}$ i.d., with 0.2 $\mu \mathrm{m}$ film thickness; Varian Inc., Oxford, UK) was used. The inlet and flame-ionization detector temperatures were $260{ }^{\circ} \mathrm{C}$, the split ratio was $15: 1$ and a $2-\mu \mathrm{L}$ injection volume was used. The hydrogen carrier gas flow to the detector was $25 \mathrm{~mL} / \mathrm{min}$, airflow was $400 \mathrm{~mL} / \mathrm{min}$, and the flow of nitrogen makeup gas was $40 \mathrm{~mL} / \mathrm{min}$. Fatty acid peaks were identified by using a fatty acid methyl ester standard (SUCPM-47885, Supelko; Bellefonte, PA, USA).

\subsection{Statistical Analysis}

The statistical processing of the data was done in the SPSS for Windows 11.5 computer programme. The differences between treatments were then estimated using the LSM method. $\mathrm{P}<0.05$ was considered significant.

\section{Results}

\subsection{Ruminal Fermentation Parameters}

The feeding ration for all groups of cows was the same, consistent with the level of milk production, live weight and day of lactation and was within the limits of the allowed content of individual nutrients.

The study of enzymatic and microbiological processes in the rumen of cows with different milk of fat content showed that the indicators of rumen digestion corresponded to the characteristics of the diet (Table 3). And if cows with normal milk fat withstood the normal characteristics of rumen digestion, then in cows with low milk fat, signs of acidosis were determined (lower $\mathrm{pH}$, acetate/propionate ratio 2.46 versus 3.5 in fat-dairy cows).

Table 3 Characteristics of ruminal fluid of cows $(M \pm S E, n=5)$

\begin{tabular}{|l|c|c|c|}
\hline \multirow{2}{*}{ Item } & \multicolumn{2}{|c|}{ Groups } & $\begin{array}{c}\text { Contrast } \\
\text { (P-value) }\end{array}$ \\
\cline { 2 - 4 } & $\begin{array}{c}\text { cows with normal } \\
\text { milk fat }\end{array}$ & $\begin{array}{c}\text { cows with low milk } \\
\text { fat }\end{array}$ & \\
\hline $\mathrm{pH}$ & $6,95 \pm 0,209$ & $6,49 \pm 0,207$ & 0.09 \\
\hline $\begin{array}{l}\text { Буферная ёмкость, мл/ед } \\
\mathrm{pH}\end{array}$ & $12,5 \pm 0,78$ & $8,5 \pm 1,20$ & \\
\hline $\mathrm{NH}$-N (mg/dl) & $5,53 \pm 2,73$ & $4,48 \pm 1,63$ & 0,44 \\
\hline VFA & & & \\
\hline
\end{tabular}




\begin{tabular}{|l|c|c|c|}
\hline Total $(\mathrm{mMol} / \mathrm{dl})$ & $9,2 \pm 1,37$ & $10,7 \pm 0,76$ & 0.17 \\
\hline Individual (mol/100mol) & & & \\
\hline Acetate & $65,6 \pm 1,36$ & $62,2 \pm 1,74$ & 0.1 \\
\hline Propionate & $18,8 \pm 0,57$ & $25,2 \pm 1,85$ & 0.02 \\
\hline Butyrate & $15,5 \pm 1,50$ & $12,4 \pm 0,61$ & 0.04 \\
\hline Bacterium $10^{6} \mathrm{ml}^{-1}$ & $9,2 \pm 0,50$ & $9,7 \pm 0,34$ & 0.34 \\
\hline Protozoa, $\mathrm{x} 10^{5} \mathrm{ml}^{-1}$ & $315 \pm 35$ & $251 \pm 73,7$ & 0.39 \\
\hline Amylolytic activity, $\mathrm{E} \mathrm{dl}^{-1}$ & $34,2 \pm 3,6$ & $32,2 \pm 0,74$ & 0.47 \\
\hline Fibrolytic activity,\% & $12,8 \pm 0,67$ & $10,2 \pm 0,65$ & 0.07 \\
\hline
\end{tabular}

At the level of enzymatic and microbiological processes in the rumen of cows, the features of cicatricial digestion were noted. Thus, cows with low milk fat had a lower rumen $\mathrm{pH}$, a high propionate level ( $\mathrm{p}<0.05$ ), and a decrease in cellulolytic activity. The study of the correlation dependences of cicatricial metabolism and milk fat content showed a direct dependence on $\mathrm{pH}(\mathrm{r}=$ $0.62 ; \mathrm{p}<0.05)$, acetate level $(\mathrm{r}=0.64 ; \mathrm{p}<0.05)$, and the ratio of acetate to propionate $(\mathrm{r}=0.82 ; \mathrm{p}$ $<0.05)$. An inverse relationship was found for propionate $(r=-0.73 ; \mathrm{p}<0.05)$.

Thus, at the level of rumen digestion, there are features in enzymatic and microbiological processes in cows of various groups, which are determined mainly by the composition of the diet. It was concluded that cows with low milk fat differ from cows with normal fat levels by a lower ability to maintain the normal course of enzymatic and microbiological processes at the level of scar digestion when feeding high amounts of concentrated feed.

\subsection{Biochemical parameters of the blood of cows}

The analysis of biochemical parameters of blood showed (Table 4) that the level of blood metabolites corresponded to the stage of lactation, productivity and characteristics of the diet, at the same time, in the blood of cows with normal milk fat content, there was a tendency to greater stress of metabolic processes, consisting in an increase in the level of cortisol and acetoaldehyde, nonesterified fatty acids and $\beta$-hydroxybutyrate. This indicates a higher rate of mobilization of the body 's fat depots to ensure the synthesis of milk components.

Table 4 Biochemical parameters of the blood of cows $(M \pm S E, n=5)$

\begin{tabular}{|l|c|c|c|}
\hline \multirow{2}{*}{ indicators } & \multicolumn{2}{|c|}{ groups } & $\begin{array}{c}\text { Contras } \\
\mathrm{t}(\mathrm{P}- \\
\text { value }\end{array}$ \\
\cline { 2 - 4 } & $\begin{array}{c}|c| \\
\text { cows with normal milk } \\
\text { fat }\end{array}$ & cows with low milk fat \\
\hline$\alpha$-amine nitrogen, mmol/L & $5,85 \pm 0,48$ & $6,03 \pm 0,193$ & 0.36 \\
\hline lipids, g/dl & $0,48 \pm 0,06$ & $0,35 \pm 0,07$ & 0.28 \\
\hline glucose, $\mathrm{mmol} / \mathrm{L}$ & $3,57 \pm 0,055$ & $3,35 \pm 0,207$ & 0.31 \\
\hline
\end{tabular}




\begin{tabular}{|l|c|c|c|}
\hline VFA, ммоль/L & $1,99 \pm 0,03$ & $2,16 \pm 0,02$ & 0.01 \\
\hline$\beta$-hydroxybutyrate, ммоль/L & $0,64 \pm 0,15$ & $0,45 \pm 0,043$ & 0.22 \\
\hline triacylglycerols, mcmol/L & $118,4 \pm 12,06$ & $99,1 \pm 12,4$ & 0.24 \\
\hline NEFA, mmol/L & $0,31 \pm 0,015$ & $0,23 \pm 0,028$ & 0.04 \\
\hline thiamine, mcg/ml & $0,1 \pm 0,006$ & $0,088 \pm 0,011$ & 0,39 \\
\hline pyruvate, mcg/ml & $8,6 \pm 1,3$ & $12,1 \pm 1,36$ & 0,117 \\
\hline $\begin{array}{l}\text { pyruvate carboxylase, } \\
\text { mmol/l/min }\end{array}$ & $2,74 \pm 0,17$ & $3,35 \pm 0,28$ & 0.075 \\
\hline $\begin{array}{l}\text { lactate dehyrogenase, } \\
\text { mmol/l/min }\end{array}$ & $21,1 \pm 2,33$ & $32,1 \pm 1,21$ & 0,001 \\
\hline acetoaldehyde, mcg/ml & $3,1 \pm 1,92$ & $0,29 \pm 0,11$ & 0,277 \\
\hline$\alpha$-tocopherol, mcg/ml & $12,9 \pm 3,23$ & $8,6 \pm 1,04$ & 0.31 \\
\hline retinol, mcg/ml & $0,33 \pm 0,0035$ & $0,29 \pm 0,014$ & 0,08 \\
\hline insulin, mked/ml & $19,9 \pm 0,56$ & $20,03 \pm 0,48$ & 0,86 \\
\hline cortisol, nmol/l & $382 \pm 32,9$ & $295 \pm 37,2$ & 0,128 \\
\hline thyroxine, ng/ml & $271,3 \pm 19,4$ & $3,38 \pm 0,18$ \\
\hline triiodothyronine, nmol/L & & $275,5 \pm 11,3$ & 0,86 \\
\hline
\end{tabular}

\subsection{Indicators of energy metabolism in cows}

This is confirmed by an increase in the efficiency of using the metabolizable energy (ME) of the diet, due to a decrease in the share of heat production (on 6.2 MJ; p=0.163) (Table 5). Cows with low milk fat content had an earlier start of a positive energy balance and a shorter service period (109.5 \pm 19.8 vs. $139 \pm 18.4$ days: $\mathrm{p}=0,194)$.

Table 5 Efficiency of using ME in cows with different fat content of milk $(M \pm S E, n=5$

\begin{tabular}{|l|c|c|c|}
\hline Item & $\begin{array}{c}\text { cows with normal milk } \\
\text { fat }\end{array}$ & cows with low milk fat & $\begin{array}{c}\text { Contrast } \\
\text { (P-value })\end{array}$ \\
\hline Metabolisable energy, MJ & $265.1 \pm 0.12$ & $265.0 \pm 0.11$ & 0,49 \\
\hline Heat production, MJ & $108,7 \pm 1.94$ & $102,5 \pm 1.14$ & 0.163 \\
\hline Heat production, \% ME & 41,0 & 38,7 & \\
\hline
\end{tabular}




\begin{tabular}{|l|c|c|c|}
\hline Milk energy, MJ & $122,9 \pm 5.12$ & $106,7 \pm 3.03$ & 0,10 \\
\hline Energy retention, MJ & $4,68 \pm 8.26$ & $30,8 \pm 4.84$ & 0,076 \\
\hline
\end{tabular}

3.4.Milk Yield and Compositions

During sampling (80-82 days of lactation), productivity indicators and milk composition slightly differed from the preliminary period (50-52 days of lactation) (Table 6). A significant difference was noted between the indicators only for the fat content in milk. Analysis of milk from cows of various groups showed that all milk had no deviations in sanitary and hygienic standards and technological properties.

Table 6 Daily milk yield and milk composition in cows $(\mathrm{M} \pm \mathrm{SE}, \mathrm{n}=10)$

\begin{tabular}{|l|c|c|c|}
\hline \multirow{2}{*}{ Item } & \multicolumn{2}{|c|}{ Groups } & Contrast (P- \\
\cline { 2 - 3 } & $\begin{array}{c}\text { cows with normal } \\
\text { milk fat }\end{array}$ & $\begin{array}{c}\text { cows with low milk } \\
\text { fat }\end{array}$ & \\
\hline Milk yield, kg/d & $39,0 \pm 1,77$ & $40,5 \pm 1,25$ & 0,21 \\
\hline Milk fat, \% & $4,1 \pm 0,24$ & $2,84 \pm 0,13$ & 0,00015 \\
\hline Milk protein, \% & $3,16 \pm 0,05$ & $3,16 \pm 0,04$ & 0,5 \\
\hline Lactose, \% & $5,08 \pm 0,08$ & $5,13 \pm 0,06$ & 0,48 \\
\hline Glucose, $\mathrm{mM} / \mathrm{L}$ & $0.34 \pm 0.123$ & $0,22 \pm 0,065$ & 0,41 \\
\hline Urea, $\mathrm{mM} / \mathrm{L}$ & $5,62 \pm 0,337$ & $5,12 \pm 0,607$ & 0,38 \\
\hline
\end{tabular}

\subsubsection{Fatty acid composition of milk lipids}

Determination of fatty acid composition of milk lipids revealed that cows of the 2nd group contained more long-chain fatty acids $45.6 \pm 1.14$ versus $43.2 \pm 1.48 ; \mathrm{p}=0.17$ ) (Table 7). This fact indicates that low milk fat in this group was primarily due to a decrease in the fat-synthesizing function of the mammary gland and only a slight decrease in fat-absorbing function (the efficiency of extraction of triacylglycerols by the udder $(32.9 \pm 5.13 \%$ versus $37.3 \pm 4,51 \%$; p $>0.05)$. An increased content of fatty acids with an odd number of atoms $\left(\mathrm{C}_{15}, \mathrm{C}_{17}\right)$ was revealed in the milk of cows with a low fat content of milk ( $<$ <0.05).

Table 7 Milk fat composition (g/100 g) (M+SE, $\mathrm{n}=5)$ 


\begin{tabular}{|c|c|c|c|}
\hline $\mathrm{C}_{8: 0}$ & $1,09 \pm 0,13$ & $0,87 \pm 0,09$ & 0,23 \\
\hline $\mathrm{C}_{10: 0}$ & $3,69 \pm 0,39$ & $3,17 \pm 0,30$ & 0,33 \\
\hline $\mathrm{C}_{11: 0}$ & $0,32 \pm 0,05$ & $0,29 \pm 0,04$ & 0,72 \\
\hline $\mathrm{C}_{12: 0}$ & $4,50 \pm 0,47$ & $3,98 \pm 0,36$ & 0,41 \\
\hline $\mathrm{C}_{13: 0}$ & $0,08 \pm 0,01$ & $0,15 \pm 0,03$ & 0,07 \\
\hline $\mathrm{C}_{14: 0}$ & $12,66 \pm 1,10$ & $12,07 \pm 0,87$ & 0,69 \\
\hline $\mathrm{C}_{14: 1}$ & $0,51 \pm 0,14$ & $0,31 \pm 0,03$ & 0,26 \\
\hline $\mathrm{C}_{15: 0}$ & $0,08 \pm 0,03$ & $0,27 \pm 0,06$ & 0,03 \\
\hline $\mathrm{C}_{15: 1}$ & $0,15 \pm 0,03$ & $0,08 \pm 0,02$ & 0,07 \\
\hline $\mathrm{C}_{16: 0}$ & $30,19 \pm 0,91$ & $29,92 \pm 0,84$ & 0,83 \\
\hline $\mathrm{C}_{16: 1}$ & $1,63 \pm 0,27$ & $1,56 \pm 0,15$ & 0,81 \\
\hline $\mathrm{C}_{17: 0}$ & $0,10 \pm 0,01$ & $0,18 \pm 0,02$ & 0,022 \\
\hline $\mathrm{C}_{17: 1}$ & $0,17 \pm 0,05$ & $0,18 \pm 0,02$ & 0,82 \\
\hline $\mathrm{C}_{18: 0}$ & $12,49 \pm 0,76$ & $11,99 \pm 0,59$ & 0,62 \\
\hline $\mathrm{C}_{18: 1}$ & $27,66 \pm 1,98$ & $30,15 \pm 1,98$ & 0,40 \\
\hline $\mathrm{C}_{18: 2}$ & $3,45 \pm 0,39$ & $3,43 \pm 0,37$ & 0,97 \\
\hline $\mathrm{C}_{18: 3}$ & $0,92 \pm 0,13$ & $1,01 \pm 0,09$ & 0,59 \\
\hline $\mathrm{C}_{20: 0}$ & $0,11 \pm 0,02$ & $0,13 \pm 0,01$ & 0,59 \\
\hline $\mathrm{C}_{20: 1}$ & $0,08 \pm 0,02$ & $0,12 \pm 0,01$ & 0,17 \\
\hline $\mathrm{C}_{20: 4}$ & $0,12 \pm 0,03$ & $0,14 \pm 0,02$ & 0,68 \\
\hline Total $\mathrm{C}_{8-16}$ & $56.8 \pm 1.48$ & $54.4 \pm 2.00$ & 0.35 \\
\hline Total $C_{16: 1-20}$ & $43.2 \pm 1.48$ & $45.6 \pm 2.00$ & 0.17 \\
\hline
\end{tabular}

\section{Discussion}

Diet significantly affects the formation and concentration of fat in the milk of dairy cows. Fat is the component of milk most influenced by diet. Diet-induced low-fat milk syndrome, milk fat depression, usually associated with feed factors [20, 21, 22, 23, 24]. Several feed factors are known to reduce milk fat, such as high levels of concentrates, fine roughage and diets high in polyunsaturated fatty acids. Usually, a change in milk fat content (decrease) is associated with an increased consumption of concentrates and, thus, a low $\mathrm{pH}$ value of the rumen contents, a low proportion of acetate and a decrease in the biohydrogenation capacity of the rumen microflora. 
Most of the proposed mechanisms that influenced milk fat content were associated with of a limited supply of lipid precursors in VFA content and a corresponding change in VFA metabolism [25]. Therefore, it was believed that low fat in milk is associated with a lack of acetate formation in the rumen, as a precursor for the synthesis of fatty acids in the mammary gland. However, the content of acetate in the contents of the rumen did not decrease $(6.03 \mathrm{mmol} / \mathrm{dl}$ and $6.65 \mathrm{mmol} / \mathrm{dl}$ in groups, respectively) (Table 3). The blood acetate level in cows with low milk fat did not differ from those in cows with normal milk fat (Table 4).

Another precursor for the formation of milk fat is $\beta$-hydroxybutyric acid. In our experiments in the rumen content, the concentration of butyric acid in cows with low milk fat was only slightly lower than in cows with normal milk fat $(1.42 \pm 0.02$ versus $1.32 \pm 0.02 ; p>0.05)$ (table 3$)$. At the same time, the content of $\beta$-hydroxybutyric acid in the blood was also slightly lower ( $p>0.05$ ) (table 4). The use of radioisotopes has shown that the acetate content does not become deficient during the depression of fat formation [26]. It was also concluded that a BHBA deficiency for milk fatty acid synthesis is not a causative factor in the decrease in milk fat production [27].

Other theories linked depression to an increase in insulin in the blood, and a deficiency of vitamin B [28]. It was suggested that the decrease in milk fat previously observed with hyperinsulinemic-euglycemic clips or with glucose [29] or propionate infusions was the most likely consequence of the ability of insulin to inhibit lipolysis, thereby limiting the availability of preformed fatty acids mobilized from body reserves in the mammary gland[30]. The involvement of thyroid hormones in the regulation of milk fat production has been reported [31]. However, neither vitamin [32] nor insulin [33] injections affected milk fat. We also did not find in the content of insulin, cortisol, thyroid hormones, or in the content of water and fat-soluble vitamins (Table 4).

Other theories have linked the low fat content of milk to direct inhibition of lipid synthesis in the mammary gland. It has been demonstrated that conjugated linoleic acid (CLA) and trans-18:1 fatty acids (LC) resulting from incomplete biohydrogenation of dietary polyunsaturated fatty acids (PUFA) in the rumen [34, 35, 36] or abomasal infusion [10, 37, 38] can significantly alter the synthesis of milk fat.

Studies of the past years confirm that the depression of fat in milk is the result of changes in the rumen biohydrogenic processes, and not changes in the rumen VFA. Rumen biohydrogenation is a process in which the polyunsaturated fatty acids (PUFA) present in the fat of the diet are hydrogenated rumen bacteria. Under normal conditions, very few unsaturated fatty acids reach the small intestine even when large amounts of PUFA are fed due to rumen biohydrogenation. The precursors of PUFA in the diets of dairy cows are linoleic acid $\left(\mathrm{C}_{18: 2}\right)$ and linolenic acid (C $\left.\mathrm{C}_{18: 3}\right)$ contained mainly in plant lipids. Infusion of PUF isomers into the post-scarring intestine leads to a depression of milk fat formation [37, 38]. A high concentration diet led to an increase in TFA in milk [39].

Short chain fatty acids $(\mathrm{C}<16)$ are the acids in milk fat that are most depleted during milk fat depression. This confirms that the mechanism by which trans fatty acids reduce total fat synthesis is de novo in reducing fatty acid synthesis. Acetyl CoA carboxylase (ACA) has been identified as a limiting enzyme for the synthesis of fatty acids in the mammary gland [40]. The measured enzyme activity together with tRNA for ASA, fatty acid synthetase and sterol CoA desaturase in the mammary gland of cows were markedly reduced in cows fed a diet that caused depression of fat formation [35, 41].

In our experiments, the fatty acid composition of milk fat did not differ in cows. There was only a slight decrease in short and medium chain fatty acids in the milk of cows with low milk fat (54.4 \pm 2.00 again $56.8 \pm 1.48 \mathrm{p}>0.35$ ) (Table 7). An increased content of fatty acids with an odd number of atoms $\left(\mathrm{C}_{15}, \mathrm{C}_{17}\right)$ was revealed in the milk of cows with a low fat content of milk $(\mathrm{p}<0.05)$ (Table 7). An increase in the composition of milk fat with its low content of $\mathrm{C}_{14}, \mathrm{C}_{16}$ and $\mathrm{C}_{17}$ was also noted in other works [42].

Thus, at present, the reason for the low fat content of milk is a violation of biohydrogenation in the rumen, and at the same time, Trans-10, cis-12-conjugated linoleic acid (CLA) is the only intermediate product that definitely suppresses the synthesis of milk fat. However, the increased 
production of trans-10 and cis-12 CLA in the rumen does not provide a universal explanation for the decrease in milk fat during diet-induced milk fat loss, suggesting that other biohydrogenation intermediates may also be involved [43]. Further research is needed to characterize the structure and function of other biohydrogenation intermediates and to consider the contribution of broader changes to rumen lipid metabolism to provide a more universal explanation for diet-induced low-fat milk syndrome (milk fat depression).

In our experiment, cows of both groups received the same diet, however, the fat content of milk was very different. Apparently, there are additional factors that allow some cows to withstand the feed load for cicatricial microbiocenosis or a different response.

Reducing the fat content of milk in the first phase of lactation by temporary artificial blocking of fat synthesis is used in practical cattle breeding to prevent excessive loss of body weight and preserve reproductive function. For this purpose, feed additives based on conjugated fatty acid are used. In such experiments carried out by us earlier [44], it was possible to reduce the release of energy with milk by $13.3 \%$ and to reduce the negative energy balance by $6.6 \mathrm{MJ}$. In the current experiment, the energy yield with milk decreased by $13.2 \%$, and the energy retention increased by $26.1 \mathrm{MJ}$ (Table 5). Cows with low milk fat had an earlier onset of positive energy balance and a shorter service period $(109.5 \pm 19.8$ vs. $139 \pm 18.4$ days: $\mathrm{P}=0.194)$. Thus, a decrease in the volume of synthesis of fatty acids in the mammary gland, as the most energy-intensive process, allows cows to reduce metabolic stress and maintain health.

The study of the subsequent milk productivity showed that by the 140th day of lactation, the fat content of milk in cows in both groups was compared and subsequently did not change between groups (Table 8).

Analysis of the duration of productive use of cows on this farm $(n=650)$ showed that the number of lactations was inversely correlated with the level of fat in milk $(\mathrm{r}=-0.68 ; \mathrm{p}<0.05, \mathrm{n}=$ 1300). Special experiments aimed at assessing the long-term effects of feeding diets that reduce fat content have not been conducted. Although it is noted that there are enough examples of apparently healthy herds that produce milk with a fat content in the range of 2.5 to $3.0 \%$, which indicates that the level of milk fat is not necessarily incompatible with "healthy" cows [21].

Table 8 Dynamics of milk yield by months

\begin{tabular}{|c|c|c|c|c|c|c|c|c|c|c|c|c|c|c|}
\hline \multirow{3}{*}{$\begin{array}{l}\mathrm{gr} \\
\text { up } \\
\mathrm{s}\end{array}$} & \multicolumn{7}{|c|}{ Milk yield, kg/d } & \multicolumn{7}{|c|}{ Milk fat, $\%$} \\
\hline & \multicolumn{6}{|c|}{ Days of lactation } & \multirow[b]{2}{*}{$\begin{array}{l}\text { ave } \\
\text { rag } \\
\text { e } \\
\text { for } \\
5 \\
\text { mo } \\
\text { nth } \\
\text { s of } \\
\text { lact } \\
\text { atio } \\
\text { n }\end{array}$} & \multicolumn{6}{|c|}{ Days of lactation } & ave \\
\hline & 50 & 80 & 110 & 140 & 170 & 200 & & 50 & 80 & 110 & 140 & 170 & 200 & $\begin{array}{l}\text { rag } \\
\text { e } \\
\text { for } \\
5 \\
\text { mo } \\
\text { nth } \\
\text { s of } \\
\text { lact } \\
\text { atio } \\
n\end{array}$ \\
\hline 1 & $\begin{array}{l}41,2 \\
\pm 1,7 \\
9\end{array}$ & $\begin{array}{l}39,0 \\
\pm 1,7 \\
7\end{array}$ & $\begin{array}{l}37,2 \\
\pm 2,7 \\
1\end{array}$ & $\begin{array}{l}35,3 \\
\pm 1,4 \\
5\end{array}$ & $\begin{array}{l}33,0 \\
\pm 2,0 \\
8\end{array}$ & $\begin{array}{l}30,0 \\
\pm 2,5 \\
1\end{array}$ & $\begin{array}{l}35 \\
95 \pm\end{array}$ & $\begin{array}{l}3,94 \\
\pm 0,1 \\
2\end{array}$ & $\begin{array}{l}4,1 \pm \\
0,24\end{array}$ & $\begin{array}{l}3,52 \\
\pm 0,0 \\
6\end{array}$ & $\begin{array}{l}3,4 \pm \\
0,17\end{array}$ & $\begin{array}{l}3,72 \\
\pm 0,2 \\
3\end{array}$ & $\begin{array}{l}3,72 \\
\pm 0,1 \\
8\end{array}$ & $\begin{array}{l}3,7 \\
\pm 0 \\
09\end{array}$ \\
\hline
\end{tabular}




\begin{tabular}{|c|c|c|c|c|c|c|c|c|c|c|c|c|c|c|}
\hline 2 & $\begin{array}{l}39,5 \\
\pm 1,5 \\
5\end{array}$ & $\begin{array}{l}40,5 \\
\pm 1,2 \\
5\end{array}$ & $\begin{array}{l}39,6 \\
\pm 1,7 \\
2\end{array}$ & $\begin{array}{r}33,8 \\
\pm 0,8\end{array}$ & $\begin{array}{l}30,6 \\
\pm 2,3 \\
1\end{array}$ & $\begin{array}{l}32,4 \\
\pm 3,5 \\
1\end{array}$ & $\begin{array}{l}36, \\
1 \pm\end{array}$ & $\begin{array}{l}2,95 \\
\pm 0,1 \\
4\end{array}$ & $\begin{array}{l}2,84 \\
\pm 0,1 \\
3\end{array}$ & $\begin{array}{l}2,91 \\
\pm 0,0 \\
9\end{array}$ & $\begin{array}{l}3,23 \\
\pm 0,2 \\
1\end{array}$ & $\begin{array}{l}4,0 \pm \\
0,28\end{array}$ & $\begin{array}{l}3,65 \\
\pm 0,2 \\
6\end{array}$ & $\begin{array}{l}3,3 \\
\pm 0, \\
11\end{array}$ \\
\hline $\mathrm{p}$ & 0,21 & 0,21 & 0,24 & 0,21 & 0,24 & 0,29 & $\begin{array}{l}0,4 \\
7\end{array}$ & $\begin{array}{l}0,00 \\
05\end{array}$ & $\begin{array}{l}0,00 \\
1\end{array}$ & $\begin{array}{l}0,00 \\
06\end{array}$ & 0,28 & 0,24 & 0,41 & $\begin{array}{l}0,0 \\
1\end{array}$ \\
\hline
\end{tabular}

\section{Conclusion}

As a result of the work done to study the functioning of the digestive system, the formation of substrates and their use in energy metabolism and the biosynthesis of milk components in the mammary gland of high-yielding cows of various butterfat milk, at the end of the first lactation phase, it was established that at the level of rumen digestion, the features of fermentation are noted that lead to change in the amount and composition of the absorbing final products of digestion, determining, to a certain extent, the composition of milk.

It was found that low fat milk is not associated with a lack of formation of acetate in the rumen and a change in the hormonal profile, but depends on the fat-synthesizing function of the breast, which is regulated by conjugated higher fatty acids. The result is a reduction in the need for cows in exchange energy, the likelihood of ketosis and prolongation of their productive use.

\section{References}

1. Kharitonov, E.L. The analysis of fodder diets for highly productive dairy cattle of various regions of the country. Dairy and beef cattle breeding 2010, 4, 16-18.

2. Dhiman T.R., Nam, S.H., Ure, A.L.: Factors affecting conjugated linoleic acid content in milk and meat. Crit. Rev. Food Sci. Nutr. 2005, 45(6), 463-482.

3. Nekrasov, R.V.; Kharitonov, E.L.; Makar, Z.N.; Duborezov, V.M.; Golovin A.V. Biosynthesis of milk components and vitality of cows with high and low-fat milk. J. of Animal Sci. 2018, 96 (№S3), 514.

4. Grimm, N.K.; Pariza, M.W. Anticarcinogens from fried ground beef: heat-altered derivatives of linoleic acid. Carcinogenesis 1987, 12(8), 1881-1887.

5. Panjushkin, D.E. Biogenesis and the function of isomers of linoleic acid in ruminants. Problems of Biology Productive Animals 2008, 3, 68-84.

6. Chouinard, P.Y.; Corneau, L.; Barbano, D.M.; Metzger, L.E.; Bauman, D.E. Conjugated linoleic acids alter milk fatty acid composition and inhibit milk fat secretion in dairy cows. J. Nutrition 1999, 129(8), 1579-1584.

7. Moore, C.E.; Hafliger, H.C.; Mendivil, O.B.; Sanders, S.R.; Bauman, D.E.; Baumgard, L.H. Increasing amounts of conjugated linoleic acid (CLA) progressively reduces milk fat synthesis immediately postpartum. J. Dairy Sci. 2004, 87(6), 1886-1895.

8. Saeb $\varnothing$, A; Saeb $\varnothing$, P.C.; Griinari, J.M.; Shingfield, K.J. Effect of abomasal infusions of

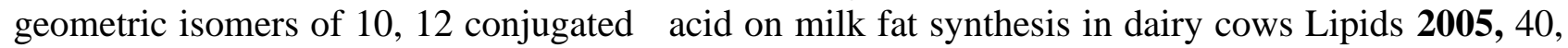
823-832.

9. Mackle, T.R.; Kay, J.K.; Auldist, M.J.; McGibbon, A.K.; Philpott, B.A.; Baumgard, L.H.; Bauman, D.E. Effects of abomasal infusion of conjugated linoleic acid on milk fat concentration and yield from pasture-fed dairy cows. J. Dairy Sci. 2003, 86(2), 644-652.

10. Chouinard, P.Y.; Corneau, L.; Saebo, A.; Bauman, D.E. Milk yield and composition during abomasal infusion of conjugated linoleic acids in dairy cows J. Dairy Sci. 1999, 82, 2737-2745. 
11. Baumgard L.H.; Corl, B.A.; Dwyer, D.A.; Saebo, A.; Bauman, D.E. Identification of the conjugated linoleic acid isomer that inhibits milk fat synthesis. Am. J. Physiol. 2000, 278(1), 179184.

12. Baumgard, L.H.; Matitashvili, E.; Corl, B.A.; Dwyer, D.A.; Bauman, D.E. Trans -10, cis -12 conjugated linoleic acid decreases lipogenic rates and expression of genes involved in milk lipid synthesis in dairy cows. J. Dairy Sci. 2002, 85(9), 2155-2163.

13. Loor, J.J.; Herbein, J.H. Reduced fatty acid synthesis and desaturation due to exogenous trans10, cis 12 CLA in cows fed oleic or linoleic oil. J. Dairy Sci. 2003, 86(4), 1354-1369.

14. Athanasion, V.; Phillips, R. Stability of plasma metabolites and hormones in parturient dairy cows. Am. Veter. Res. 1978, 39(7), 953-956.

15. Kurilov, N.V.; Kharitonov, L.V.; Sevast'janova, N.A. Study digestion in ruminants. Methodical instructions, Borovsk, 1987; 105 p.

16. Nadalyak, E.A.; Agafonov, V.I.; Reshetov, V.B. The study of energy metabolism and energy nutrition in farm animals.: method. instructions, Borovsk, 1986; p. 58.

17. Mitsukava, H.; Shimizu O.; Nishi H. Colorimetric determination of $\alpha$-amino nitrogen in urine and plasma with ninhydrin reaction. Agr. Biol. Chem. 1971, 35(2), 272-274.

18. Scrutton, M.S.; Wnite, D.M. Piruvate carboxylase specific inactivation of acetyl-CoAdependent oxaloacetate synthesis during modification of the enzyme by trinitrobensene sulfonate. J. Biol. Chem. 1973, 248(15), 541-544.

19. Folch, J.; Lees, M.; Sloane-Stanley, G. A simple method for the isolation and purification of total lipids from animal tissues. J. Biol. Chem. 1957, 226, 497-509.

20. Sutton, J. D. Altering milk composition by feeding. J. Dairy Sci. 1989, 72, 2801-2814.

21. Kennelly, J.J. Producing milk with $2.5 \%$ fat -- the biology and health implications for dairy cows. Animal Feed Science and Technology. 1996, 60(3-4), 161-180.

22. Bauman, D.E.; Griinari, J.M Regulation and nutritional manipulation of milk fat: low-fat milk syndrome. Livestock Production Science. 2001, 70 (1-2), 15-29.

23. Shingfield, K.J.; Griinari, J.M. Role of biohydrogenation intermediates in milk fat depression. European Journal of Lipid Science and Technology 2007,109,799-810.

24. Maxin, G.; Rulquin, H.; Glasser F. Response of milk fat concentration and yield to nutrient supply in dairy cow.s Animal. 2011, 5, 1299-1310.

25. Van Soest, P.J. Nutritional ecology of the ruminant. Comstock Pub., Ithaca.P. 1994; pp. 334336.

26. Davis, C.L.; Brown R.E. Low-fat milk syndrome. In Physiology of digestion and metabolism in the ruminant (ed. AT Phillipson) Oriel Press, Newcastle upon Tyne, UK. 1970; pp. 545-565.

27. Palmquist, D.L.; Davis, C.L.; Brown, R.E.; Sachan, D.S. Availability and metabolism of various substrates in ruminants. V. Entry rate into the body and incorporation into milk fat of $\beta$ hydroxybutyrate. J. of Dairy Sci. 1969, 52, 633-638.

28. Griinari J.M., McGuire M.A., Dwyer D.A., Bauman D.E., Palmquist D.L. Role of insulin in the regulation of milk fat synthesis in dairy cows Journal of Dairy Science. 1997, 80 (6), 1076-1084.

29. Rigout, S; Lemosquet, S; Bach, A.; Blum, J.W.; Rulquin, H. Duodenal infusion of glucose decreases milk fat production in grass silage-fed dairy cows J. of Dairy Sci. 2002, 85, 2541-2550.

30. Corl, B.A.; Butler, S.T.; Butler, Wmmmm.R.; Bauman, D.E. Regulation of milk fat yield and fatty acid composition by insulin. J. of Dairy Sci. 2006, 89, 4172-4175.

31. Harvatine, K.J.; Bauman, D.E. SREBP1 and thyroid hormone responsive spot 14 (S14) are involved in the regulation of bovine mammary lipid synthesis during diet-induced milk fat depression and treatment with CLA. J. of Nutrition, 2006, 136, 2468-2474.

32. Croom, W. J.; Rakes, A. H.; Linnerud, A. C.; Ducharme, G. A.; Elliot J. M. Vitamin B administration for milk fat synthesis in lactating dairy cows fed a low fiber diet. J. Dairy Sci. 1981, 64, 1555-1560.

33. McGuire, M. A.; Griinari, J. M.; Dywer, D. A.; Bauman, D. E. Role of insulin in the regulation of mammary synthesis of fat and protein. J. Dairy Sci. 1995, 78, 816-824. 
34. Griinari, J. M.; Dwyer, D. A.; McGuire, M. A.; Bauman, D. E.; Palmquist D. L.; Nurmela, K. V. V. 1998. Trans-octadecaenoic acids and milk fat depression in lactating dairy cows. J. Dairy Sci. 1998, 81, 1251-1261.

35. Piperova, L. S.; Teter, B. B.; Bruckental, I.; Sampagna, J.; Mills S. E.; Yurawecz M. P.; Fritsche J.; Ku K.; Erdman R. A. Mammary lipogenic enzyme activity, trans fatty acids and conjugated linoleic acid isomers during milk fat depression in lactating dairy cows. J. Nutr. 2000, 130, 2568-2574.

36. Peterson, D.G.; Matitashvili, E.A.; Bauman, D.E. Diet induced milk fat depression in dairy cows results in increased trans-10, cis-12 CLA in milk fat and coordinate suppression of mRNA abundance for mammary enzymes involved in milk fat synthesis. J. Nutr., 2003, 133, 3098-3102.

37. Gaynor,P.J.; Erdman R.A.; Teter B.B.; Sampugna J.; Capuco A.V.; Waldo D.R.; Hamosh M. Milk fat yield and composition during abomasal infusion of cis or trans octadecenoates in Holstein cows. J. Dairy Sci. 1994, 77, 157-165.

38. Romo, G.A.; Casper, D.P.; Erdman, R.A.; Teter, B.B. Abomasal infusion of cis or trans fatty acid isomers and energy metabolism of lactating dairy cows. J. Dairy Sci. 1996, 79, 2005-2015.

39. Kalscheur, K. R; Teter B. B.; Piperova L. S.; Erdman, R. A. Effect of fat source on trans fatty acid flow and milk fat production in lactating dairy cows. J. Dairy Sci. 1997, 80, 2115-2126 40. Mellenberger, R. W.; Bauman, D. E.; Nelson, D. E. 1973. Fatty acid and lactose synthesis in cow mammary tissue. Biochem J. 1973, 136,741-748.

41. Loor, J. J.; Herbein J. H. Exogenous conjugated linoleic acid isomers reduce bovine milk fat concentration and yield by inhibiting de novo synthesis. J. Nutr. 1998, 128, 2411-2419.

42. Kadegowda, A.K.G.; Piperova, L.S.; Erdman, R.A. Principal component and multivariate analysis of milk long-chain fatty acid composition during diet-induced milk fat depression. J. of Dairy Sci. 2008, 91, 749-759.

43. Shingfield, K.J; Griinari, J.M. Role of biohydrogenation intermediates in milk fat depression. European Journal of Lipid Science and Technology, 2007, 109,799-816.

44. Kharitonov, E.L. The Absorption of the Precursors of Milk Components by the Udder of Cows. Agricultural Innovation Systems 2021, 2, 670-679. (doi: 10.1007/978-3-030-91405-9_74) 